\title{
Effect of dietary inclusion of Soybean Cheese residue on performance, economics of production and egg quality of layers
}

\author{
Oyewole Benjamin Osigbodi * \\ Department of Animal Production, Kogi State University, Anyigba, Kogi State, Nigeria.
}

GSC Biological and Pharmaceutical Sciences, 2022, 18(02), 253-258

Publication history: Received on 10 January 2022; revised on 19 February 2022; accepted on 21 February 2022

Article DOI: https://doi.org/10.30574/gscbps.2022.18.2.0075

\begin{abstract}
8 weeks feeding trial was undertaken to evaluate soybean cheese residue (SCR) with 29 weeks old layers. SCR was incorporated at $0,5,10,15$ and $20 \%$ in diets T1, T2, T3, T4, and T5 respectively. Ninety (90) twenty-nine week old birds were used for the experiment. The birds were allocated to the five diets in a Completely Randomized Design (CRD). Each treatment had eighteen (18) birds such that each replicate had six (6) birds. There were no observed significant differences ( $>0.05)$ in final weight and weight gain. Hen day production, daily feed intake, feed conversion ratio, feed cost $/ \mathrm{kg}$, feed cost/egg crate and profit indicated significant differences ( $p>0.05$ ). HDP ranged from $39.73 \%$ to $49.64 \%$. Feed intake was $101.25 \mathrm{~g}$ to $117.20 \mathrm{~g}$. Feed conversion ratio showed value range of 3.83 to 4.19 . Feed cost $/ \mathrm{kg}$ had a value range of $\$ 90.00$ to $\$ 170.00$. Feed cost/egg crate showed value range of $\$ 702.89$ to $\$ 834.28$. Value for profit ranged from $\$ 74.43$ to $\$ 447.26$. Supplementation of SCR influenced the performance and profitability of the layers. Egg quality characteristics were measured at intervals and average computed for each diet. Egg weight, egg length and egg width were significantly affected $(\mathrm{P}<0.05)$ in favour of SCR diets. But shell weight and shell thickness were similar for all the diets. Egg content weight and yolk weight were significantly $(\mathrm{P}<0.05)$ affected, while albumen height, yolk diameter, yolk height and Haugh unit were similar. The values observed for egg weight, egg length, egg width, egg shell weight, shell thickness 53.47-54.88g, 3.65-3.87 cm, 2.68-2.71 cm, 7.43-7.61 g and 0.54-0.59 mm respectively. Egg content weight, albumen Height, yolk diameter, yolk weight and Haugh unit ranged from $45.8749 .09 \mathrm{~g}, 5.21-5.81 \mathrm{~cm}$, 2.49-2.81 cm, $1.27-1.31 \mathrm{~cm}, 13.78-18.10 \mathrm{~g}$ and 73.86-78.10 respectively. The addition of SCR increased profit because it reduced cost of production besides promoting better productivity. Furthermore, SCR inclusion in the diet of layers did not affect egg quality adversely. The inclusion of SCR in layer diet is recommended even up to $20 \%$.
\end{abstract}

Keywords: Soybean cheese residue; Hen day production; Crate; Profitability; Egg quality

\section{Introduction}

As the world population increases every year, so is the animal protein intake deficit in the developing country such as Nigeria. According to Iyagbe and Orewa [1], the average Nigerian consumes 6-8 g per day of animal protein as against the Food and Agriculture Organization recommendation of $35 \mathrm{~g}$. This short fall can partly be attributed to the high cost of animal products, which is the consequence of high cost production of farm animals. More also, the high cost of production cannot be separated from feed cost, which is about 60-80 \% of the cost of production of livestock [2]. Oyewole et al. [3] asserted that feed cost is one of the variables which contribute to high cost of poultry, despite its potential to bridge the demand and supply gap [4] in animal protein for the populace. This pitiable scenario has further been compounded by insecurity that has affected crop farming activities, besides erratic weather conditions, humanlivestock competition for grains and declining purchasing power of many citizens of Nigeria.

\footnotetext{
* Corresponding author: Oyewole Benjamin Osigbodi; Email: oyewole.bo@ksu.edu.ng Department of Animal Production, Kogi State University, Anyigba, Kogi State, Nigeria. 
Therefore, to provide cheap animal protein, the plausible option to the high cost of feed is the evaluation of nonconversional feed stuffs or crop wastes which are not being consumed by man. This approach may however, reduce feed cost and, invariably cost of production, and as well as improve profit margin of the farmer. Soybean cheese residue (SCR), a by-product of soybean cheese production is a potential feedstuff for layers. SCR is beige in colour and has a light crumbly, fine grained texture which makes it look like moist sawdust or grated coconut and tastes similar to almond [5]. Abd-Elsamee et al. [6] reported that SCR replaced 60\% soybean meal in poultry diet without any adversely effect on growth performance but improved economic efficiency. The feeding trial was conducted to evaluate the effect varied levels of soybean cheese residue on the performance, economics of production and egg quality of layers.

\section{Material and methods}

The feeding trial was undertaken at the Poultry Unit of the Livestock Teaching and Research Farm of Kogi State University, Anyigba. The soybean cheese residue that was used was collected from soybean cheese vendors, sundried and milled, before it was incorporated at 0, 5, 10, 15 and $20 \%$ in diets T1, T2, T3, T4, and T5 (Table 1) respectively.

Table 1 Percentage Composition of Layer Diets Containing Graded Levels of Soybean Cheese Residue

\begin{tabular}{|l|c|c|c|c|c|}
\hline \multicolumn{1}{|c|}{ Ingredient } & T1 & T2 & T3 & T4 & T5 \\
\hline Maize & 56.00 & 53.00 & 50.00 & 47.00 & 44.00 \\
\hline Full fat soybean & 29.10 & 27.10 & 25.10 & 23.10 & 21.10 \\
\hline Brewer dried grains & 4.45 & 4.45 & 4.45 & 4.45 & 4.45 \\
\hline Soybean Cheese Residue & 0.00 & 5.00 & 10.00 & 15.00 & 20.00 \\
\hline Bone Meal & 4.50 & 4.50 & 4.50 & 4.50 & 4.50 \\
\hline Limestone & 5.00 & 5.00 & 5.00 & 5.00 & 5.00 \\
\hline Methionine & 0.20 & 0.20 & 0.20 & 0.20 & 0.20 \\
\hline Salt & 0.30 & 0.30 & 0.30 & 0.03 & 0.30 \\
\hline Lysine & 0.20 & 0.20 & 0.20 & 0.20 & 0.20 \\
\hline Premix & 0.25 & 0.25 & 0.25 & 0.25 & 0.25 \\
\hline Total & 100 & 100 & 100 & 100 & 100 \\
\hline Calculated & 17.66 & 17.50 & 17.33 & 17.17 & 17.01 \\
\hline Protein & 2993.47 & 293877 & 2884.07 & 2829.36 & 2774.66 \\
\hline Energy (Kcal/kg) & \multicolumn{5}{|r|}{} \\
\hline
\end{tabular}

Ninety (90) twenty-nine week old birds were used for the experiment on deep litter. The birds were weighed and randomly allocated to the five diets in a Completely Randomized Design (CRD). Each treatment had eighteen (18) birds such that each replicate had six (6) birds. The experiment lasted for eight weeks. Feed and potable drinking water were provided ad libitum and standard routine management practices were be followed. Initial weight of birds was determined by weighing the birds per replicate at the beginning of the experiment and then dividing the weight by the number of birds per replicate. Daily feed intake was determined by the difference between daily feed offered and daily feed leftover. Final weight was taken at the end of the experiment and the overall weight gain was obtained by subtracting the initial weight from the final weight. Feed conversion ratio (FCR) was calculated using the formula shown below:

$$
\mathrm{FCR}=\frac{\text { Feed Intake }}{\text { Crate of Eggs }}
$$

The economics of inclusion of SCR was also estimated. Egg Weight was measured in gram (g) using a sensitive electronic scale. The eggs were picked a day before the weighing and cleaned thoroughly with tissue paper to remove any faecal material before weighing. Egg shell thickness was measured in millimeter ( $\mathrm{mm}$ ) using a micro meter screw guage. The 
shell was cleaned with tissue paper before reading was taken. Egg shell weight was measured in gram using a sensitive electronic weighing scale. The shell was cleaned with a tissue paper to remove any trace of albumin before weighing. Egg content was poured into a flat plate of known weight and weighed $\left(\mathrm{W}_{1}\right)$ to get the egg content weight. The yolk was carefully removed and weighed to obtain yolk weight. The new weight $\left(\mathrm{W}_{2}\right)$ was taken as albumin weight. Egg yolk diameter was determined in $\mathrm{cm}$ by a vernier caliper as the distance between the opposite edges of the yolk. Egg yolk height was measured with the aid of vernier caliper. Haugh unit was estimated using the following equation by Haugh [7]:

$$
\mathrm{HU}=100 \log \left(\mathrm{H}+7.57-1.70 \mathrm{~W}^{0.37}\right)
$$

Where:

$\mathrm{H}=$ Observed albumen height $(\mathrm{mm})$

$\mathrm{W}=$ Observed weight of Egg (g)

All data collected were statistically analyzed using Analysis of Variance (ANOVA) with the aid of SPSS Computer Statistical Package. Where significant effects were obtained, means were separated with Duncan's multiple range test with the aid of the same software [8].

\section{Results}

Table 2 shows the performance of layers fed diets containing graded levels of SCR. There was no observed significant difference $(p>0.05)$ in final weight, and weight gain. Hen day production, daily feed intake, feed conversion ratio, feed cost $/ \mathrm{kg}$, feed cost/egg crate and profit had significant difference ( $p>0.05$ ). Value range of $39.73 \%$ to $49.64 \%$ was obtained for hen day production. Feed intake showed a range of $101.25 \mathrm{~g}$ to $117.20 \mathrm{~g}$. Feed conversion ratio showed value range of 3.83 to 4.19 . Feed cost $/ \mathrm{kg}$ had a value range of $\$ 90.00$ to $\$ 170.00$. Feed cost/egg crate showed value range of $\$ 702.89$ to $\$ 834.28$. Value for profit ranged from $\$ 74.43$ to $\$ 447.26$ [8].

Table 2 Performance and Economics of Layers Fed Graded Levels of Soybean Cheese Residue

\begin{tabular}{|l|c|c|c|c|c|c|c|}
\hline \multicolumn{1}{|c|}{ Parameters } & T1 & T2 & T3 & T4 & T5 & SEM & LOS \\
\hline Live Weight/bird (kg) & 1.65 & 1.64 & 1.66 & 1.63 & 1.62 & 0.13 & NS \\
\hline Final weight/bird (kg) & 1.66 & 1.65 & 1.67 & 1.63 & 1.62 & 0.29 & NS \\
\hline Weight gain/bird (g) & 12.01 & 9.40 & 10.31 & 3.01 & 2.34 & 9.82 & NS \\
\hline Hen day production (\%) & $39.73^{\mathrm{b}}$ & $47.68^{\mathrm{ab}}$ & $41.16^{\mathrm{b}}$ & $49.64^{\mathrm{a}}$ & $44.14^{\mathrm{b}}$ & 2.13 & $*$ \\
\hline Feed Intake/bird (g) & $101.25^{\mathrm{b}}$ & $102.50^{\mathrm{b}}$ & $117.20^{\mathrm{a}}$ & $103.39^{\mathrm{b}}$ & $101.85^{\mathrm{b}}$ & 2.78 & $*$ \\
\hline FCR & $3.84^{\mathrm{a}}$ & $3.90^{\mathrm{a}}$ & $3.97^{\mathrm{a}}$ & $3.83^{\mathrm{a}}$ & $4.19^{\mathrm{b}}$ & 0.09 & $*$ \\
\hline Feed Cost/Kg ( $)$ & $170.00^{\mathrm{a}}$ & $150.00^{\mathrm{a}}$ & $130.00^{\mathrm{b}}$ & $110.00^{\mathrm{b}}$ & $90.00^{\mathrm{c}}$ & 15.25 & $*$ \\
\hline Feed cost/Egg Crate ( $\mathrm{N})$ & $834.28^{\mathrm{a}}$ & $801.49^{\mathrm{a}}$ & $757.28^{\mathrm{b}}$ & $702.89^{\mathrm{b}}$ & $719.91^{\mathrm{b}}$ & 19.97 & $*$ \\
\hline Profit/bird ( $\mathrm{N})$ & $74.43^{\mathrm{d}}$ & $222.45^{\mathrm{c}}$ & $177.17^{\mathrm{b}}$ & $447.26^{\mathrm{a}}$ & $427.12^{\mathrm{a}}$ & 13.92 & $*$ \\
\hline Mortality ( & $0.00^{\mathrm{a}}$ & $5.55^{\mathrm{b}}$ & $0.00^{\mathrm{a}}$ & $5.55^{\mathrm{b}}$ & $0.00^{\mathrm{a}}$ & 0.50 & $*$ \\
\hline
\end{tabular}

$\mathrm{a}, \mathrm{b}, \mathrm{c}, \mathrm{d}$ Means with different superscripts along the same row are significantly different at $\mathrm{p}<0.05$. FCR $=$ feed conversion ratio, SEM= Standard Error of the Mean. NS: not significant at $p>0.05$, LOS=Level of Significance.

Table 3 shows that egg weight, egg length, shell thickness and egg width were significantly different $(\mathrm{P}<0.05)$ with diet, whereas shell weight and thickness were not significantly different $(\mathrm{P}>0.05)$. The values observed for egg weight, egg length, egg width, egg shell weight, shell and thickness ranged from 53.47-54.88 g, 3.65-3.87 cm, 2.68-2.71 cm, 7.43 $7.61 \mathrm{~g}$ and $0.54-0.59 \mathrm{~mm}$ respectively.

Table 4 shows the internal qualities of eggs of bird fed diets containing graded levels of soybean cheese residue. Egg content weight, albumen height, yolk diameter, yolk height, yolk weight and Haugh unit which ranged from 45.87-49.03 g, 5.21-5.81 cm, 2.49-2.81 cm, 1.27-1.31 cm, 13.78-18.10 g and 73-86-78.10 g respectively. 
Table 3 External Egg Qualities of Layer Fed Diet Containing Soybean Cheese Residue

\begin{tabular}{|l|c|c|c|c|c|c|c|}
\hline Parameters & T1 & T2 & T3 & T4 & T5 & SEM & LOS \\
\hline Egg Weight (g) & $53.47^{\mathrm{d}}$ & $54.75^{\mathrm{b}}$ & $54.25^{\mathrm{bc}}$ & $53.61^{\mathrm{c}}$ & $54.88^{\mathrm{a}}$ & 0.13 & $*$ \\
\hline Egg Length (cm) & $3.87^{\mathrm{a}}$ & $3.85^{\mathrm{ab}}$ & $3.82^{\mathrm{b}}$ & $3.71^{\mathrm{c}}$ & $3.65^{\mathrm{d}}$ & 0.09 & $*$ \\
\hline Egg Width (cm) & $2.70^{\mathrm{b}}$ & $2.71^{\mathrm{a}}$ & $2.69^{\mathrm{cd}}$ & $2.69^{\mathrm{cd}}$ & $2.68^{\mathrm{d}}$ & 0.001 & $*$ \\
\hline Egg Shell Weight (g) & 7.51 & 7.43 & 7.57 & 7.48 & 7.61 & 0.15 & NS \\
\hline Egg Shell Thickness (mm) & 0.54 & 0.56 & 0.57 & 0.58 & 0.59 & 0.04 & NS \\
\hline
\end{tabular}

$\mathrm{a}, \mathrm{b}, \mathrm{c}=$ means with different superscript $(\mathrm{P}>0.05)$ different, SEM = Standard error mean, LOS= Level of Significance, NS= Not Significant $(\mathrm{P}>0.05)$, $*$ Significant $(\mathrm{P}<0.05)$.

Table 4 Internal Qualities of Layer Fed Diet Containing Soybean Cheese Residue

\begin{tabular}{|c|c|c|c|c|c|c|c|}
\hline Parameters & $\mathbf{T 1}$ & $\mathbf{T 2}$ & T3 & $\mathbf{T 4}$ & T5 & SEM & LOS \\
\hline Egg Content Weight (g) & 45.87 & 47.51 & 48.48 & 48.91 & 49.03 & 1.33 & NS \\
\hline Albumen Height $(\mathrm{cm})$ & 5.81 & 5.33 & 5.27 & 5.23 & 5.21 & 0.83 & NS \\
\hline Yolk Diameter (cm) & 2.49 & 2.57 & 2.61 & 2.73 & 2.81 & 3.08 & NS \\
\hline Yolk Height $(\mathrm{cm})$ & 1.31 & 1.30 & 1.29 & 1.28 & 1.27 & 0.06 & NS \\
\hline Yolk Weight (g) & $18.10^{\mathrm{a}}$ & $16.00^{\mathrm{b}}$ & $15.10^{c}$ & $14.00^{\mathrm{d}}$ & $13.78^{\mathrm{e}}$ & 1.31 & $*$ \\
\hline Haugh Unit & 78.10 & 73.86 & 75.86 & 76.58 & 74.57 & 6.12 & NS \\
\hline
\end{tabular}

\section{Discussion}

The observed live weight is an indication that the birds were still growing, i.e., gained weight while laying. More so, the experimental diets supported egg production and weight gain for the duration of the feeding trial. This may suggest that inclusion of SCR did not impose any nutritional stress on the birds. Hen day production of $39.73 \%$ to $49.64 \%$ was far lower than $70.23 \%$ to $76.45 \%$ (7), 62.41-67.05 \% (8), 55.35-61.00\% [9] and 41.60-48.80\% [9]. Differences in observed HDP may due to variations in diet composition, breed or strain of layers used, age, feed intake, health condition, environmental conditions and season of the experiment. However, all the birds can draw from their body reserve for egg production since average body weight is above $1.3 \mathrm{~kg}$ [10]. Feed intake of $101.24 \mathrm{~g}$ to $117.20 \mathrm{~g}$ may suggest the acceptability of the diets, especially the SCR based diets relative to the control. Observed FCR is within 3.20 to 4.34 reported by [11]. However, [12] reported 1.91 to 2.27 for layers at different seasons in the semi-humid tropics. Feed cost/kg declined with SCR inclusion. This is due to the fat that SCR is cheaper than full fat soybean and maize which it replaced. The steady decrease in price of feed $/ \mathrm{kg}$ is a potential reduction in the overhead cost due to feed. It has been reported that feed cost differs significantly with use of non-conventional feed [12]. More so, inclusion of SCR resulted in more economic egg production, and consequently profitability [8]. The egg weight observed is lower than 59.50-64.50 $\mathrm{g}$ for European commercial strain and $63 \mathrm{~g}$ Olympic black layers [13] and 43.67-58.33 g [9]. However, egg weight appeared to be in favour of diets containing SCR. Egg length declined with inclusion of SCR. Birds on the control diet had the highest length. The observed range for egg length is lower than 43.00-47.56 mm reported by Onunkwo and Okoro [14]. Egg width seem to decrease also with inclusion of SCR except at $5 \%$ level. The width of the eggs from this study are lower than those reported by Aberra et al. [15] and Markos et al. [16]. This may be ascribed to the stage of egg lay, as it has been reported that at the beginning of egg lay the eggs are usually smaller and larger eggs are laid prior to moulting [17]. The shell thickness observed for the treatments is higher than minimum recommended shell thickness for layer chicken eggs, i.e., $0.33 \mathrm{~mm}$ [18]. This is an indication that the shell thickness is adequate, hence the eggs may withstand the stress of transportation and handling without cracking. Observed external quality parameters show that SCR inclusion in the diets did not compromise external egg quality. The observed egg content values may indicate that SCR inclusion resulted in heavier egg content, which is also the edible portion of the egg. This parameter increased with inclusion level of SCR. The study showed that SCR elicited similar effect on albumen height, yolk diameter, yolk height and Haugh unit. This may suggest that inclusion of SCR did not compromise the freshness of the eggs. However, inclusion of SCR in the diets progressively lowered the weight of the egg yolk as inclusion level increased. 


\section{Conclusion}

Observed results from the study show SCR in the diet influenced the performance, egg production and profitability of the layers. The addition of SCR increased profit because it reduced cost of production besides promoting better productivity with heavier egg content. More so SCR inclusion did not compromise both external and internal quality of eggs even at $20 \%$ inclusion level. Based on the result from the feeding trial, the inclusion of SCR in layer diet is recommended even up to $20 \%$.

\section{Compliance with ethical standards}

\section{Acknowledgments}

The researcher wishes to acknowledge the Authorities of Kogi State University Anyigba who provided the facilities that were used on the Livestock Teaching and Research Farm. Mrs. Amina Oyibo who provided technical support is hereby acknowledged. I wish to also appreciate Mr. Ismaila Muhammed Onimisi for assisting with data collection.

\section{Disclosure of conflict of interest}

The Author hereby declare that no conflict of interest exists.

\section{Statement of ethical approval}

The research complied with the ethical standards of Kogi State University, Anyigba, Nigeria.

\section{References}

[1] Iyangbe CO, Orewa SI. (2009). Determinants of Daily Protein Intake among Rural and Low-Income Urban Houses in Nigeria. American-Eurasian Journal of Scientific Research, 4(4): 209-301.

[2] Ogundipe SO, Abeke FO, Sekoni AA, Dafwang II, Adeyinka AI. (2003). Effect of duration of cooking on the utilization of lab labpurpureus by pullet chicks. In: Proceedings of the 28th Annual conference of the Nigerian Society for Animal Production held at Ibadan, Nigeria. Pp. 233-235.

[3] Oyewole BO, Olarenwaju G, Dafwang II. (2013). Performance of Broilers Fed Premix Prepared from Locally Sourced Materials. Standard Research Journal of Agricultural Sciences, 1(2): 17-20.

[4] Padhi MK. (2016). Importance of indigenous breeds of chicken for Rural Economy and their Improvement for higher production performance. Scientifica. Article 2604685: 1-9. https://doi.org/10.1155/2016/2604685

[5] Dikko IM, Yakubu AH, Doma UD, Lakurbe OA, Maigado AI, Bello IU. (2018). Effects of Awara Residue Meal on Haematology and Biochemical Indices of Broiler Chickens. PAT Journal, Nassarawa State University Keffi, 14(1): 91-97.

[6] Abd-Elsamee MO, Ibrahim MRM, Abd-Elkrim FM. (2005) Use of some plant Protein sources in broiler diets. Journal of Agricultural Science. Mansoura University, 20(12): 7495-7506.

[7] Haugh RR. (1937). Egg Quality. The US Egg and Poultry Magazine, September. Pp. 552-555.

[8] Oyewole BO. Performance and Economics of Production of Layers Fed Soybean Cheese Residue Diets. (2021). Proceedings of 26th Annual Conference of ASAN-NIAS, Uyo, Nigeria. 2021, 26:295-298.

[9] Oyewole B0, Abraham J, Atama DU. (2016). Performance and Egg Quality of ISA Brown Layers Fed Toasted Bambara Nut Waste Meal Based Diets. International Journal of Agricultural and Veterinary Sciences, 2(2): 33-40.

[10] Oyewole BO, Ojotule B, Salihu A. (2018). Performance, Egg Qualities, and Blood Parameters of Layers Fed Diets Containing Graded Levels of Sundried Sweet Orange Fruit Peel Meal. Agricultural Extension Journal [S.l.]. 2018; (2): 125-131.

[11] Zaman MA. (2002). Egg production performance of different breed/breed combinations of chicken Semiscavenging system under Participatory Livestock Development Programme (PLDP). Department of animal breeding and Genetics. Danish Institute of Agricultural Sciences, Foulum, Denmark. Unpublished M.Sc. Thesis. $\mathrm{p} 22$. 
[12] Yakubu A, Salako AE, Ige AO. (2007). Effects of genotype and housing system on the laying performance of chickens in different seasons in the semi-humid tropics, International Journal of Poultry Science, 6: 434-439.

[13] Chineke CA. (2001). Interrelationship Existing Between Body Weight and Egg Production Traits in Olympia Black Layers. Nigerian Journal of Animal Production, 28(1): 1-8.

[14] Onunkwo DN, Okoro IC. (2015). External and internal egg qualities characteristics of three varieties of helmeted guinea fowl (Numida meleagris) in Nigeria. International Journal of Current Research Review, 7(7): 11-17.

[15] Aberra M, Zemen W, Yosef TG. (2012). Assessment of the prevailing handling and quality of eggs from scavenging indigenous Chickens reared in different agro-ecological zone of Ethiopia. Research Journal of Poultry Science, 5(4-6): 64-70.

[16] Markos S, Belay B, Astatkie T. (2017). Evaluation of Egg Quality Traits of Three Indigenous Chicken Ecotypes Kept Under Farmers' Management Conditions. International Journal of Poultry Science, 16(5): 180-188.

[17] Padhi MK, Chatterjee RN, Haunshi S, Ullengala R. (2013). Effect of age on egg quality in chicken. Indian Journal of Poultry Science, 48(481): 122-125.

[18] Stadelman WJ. (1977). Quality identification of shell eggs in egg science and technology. 2nd ed. Westport, Connecticut: AVI Publishing Company Inc. p33. 